\title{
Blood transfusion service in Poland in 2020
}

\author{
Aleksandra Rosiek $\odot$, Anna Nieradkiewicz $\odot$, Elżbieta Lachert $\odot$, \\ Jolanta Antoniewicz-Papis $\odot$, Paulina Goczyńska $\odot$, Ryszard Pogłód $\odot$, \\ Magdalena Łętowska $\odot$
}

Department of Transfusion Medicine, Institute of Hematology and Transfusion Medicine in Warsaw

\begin{abstract}
Summary
Background: The aim of this study was to present the basic aspects of the activity of Polish blood transfusion service (hereinafter referred to as Centers) in 2020, taking into account the conditions related to the ongoing COVID-19 pandemic.
\end{abstract}

Materials and methods: Analysis of data forwarded to the Institute by the Polish Blood Transfusion Centers (Centers).

Results: In 2020, 23 Centers and 136 local collection sites operated in Poland. Blood and blood components were also collected during 10,432 mobile collections. The overall number of blood donors was estimated at 569,914, the majority of which were non-remunerated donors (569,566, including 50,012 responders to donation appeals) as well as 25 remunerated donors and 323 autologous donors. Most frequent were whole blood collections $(1,105,434)$ and the least frequent - granulocyte concentrate collections (82) and RBC collections by apheresis (16). Whole blood was collected mostly in local collection sites (46.84\%), less frequently in Centers (30.62\%) and mobile collection sites (22.54\%). The most frequently prepared blood components were RBCs (1,089,978 units) and FFP (1,264,654 units). COVID-19 convalescent plasma was also collected (57 708 units).

In 2020, a total of 77,485 units of PCs pooled from whole blood and 52,030 units of PCs from apheresis were prepared.

Additional processing methods (leukocyte depletion, irradiation) were more frequently applied to PCs (55.47\% leukodepleted, $44.53 \%$ both leuko-depleted and irradiated), than to RBC (21.03\% leukodepleted, $9.85 \%$ both leukodepleted and irradiated, 0.06\% irradiated). Pathogen inactivation technologies were applied to $14.21 \%$ of FFP units issued for clinical use and $11.01 \%$ of PCs. For various reasons the following amounts of blood components were wasted in 2020:11,430 units of whole blood, 29,530 units of RBCs, 53,946 units of FFP, 1,691 units of apheresis PCs, 5,455 units of pooled PCs and 1,381 units of cryoprecipitate.

As compared to the previous years, in 2020 almost all the indicators of the activity of the blood transfusion service in Poland have markedly decreased.

Conclusions: The data presented in this study point to the significant impact that the COVID-19 pandemic had on blood donation in Poland in 2020. The data may serve as a starting point for the analysis of issues related to the activity of organizational units of the Polish blood transfusion service and contribute to practical benchmarking. This in turn may prove beneficial to the transfusion community as a whole.

Key words: blood donors, blood donation, blood components, COVID-19

J. Transf. Med. 2021; 14: 176-193

Correspondence address: dr n. med. Aleksandra Rosiek, Department of Transfusion Medicine, Institute of Hematology and Transfusion Medicine in Warsaw, Indiry Gandhi Street 14, 02-776 Warsaw, phone: (22) 349 63 91, fax: (22) 349 63 76, e-mail: arosiek@ihit.waw.pl Translation: mgr Krystyna Dudziak

This article is available in open access under Creative Common Attribution-Non-Commercial-No Derivatives 4.0 International (CC BY-NC-ND 4.0) license, allowing to download articles and share them with others as long as they credit the authors and the publisher, but without permission to change them in any way or use them commercially. 


\section{Introduction}

The activity of Polish blood transfusion service (BTS) is regulated by the Public Blood Transfusion Service Act of August 22, 1997 [1]. Pursuant to this Act, the following units of the public blood transfusion service are entitled to collect blood and prepare blood components: 21 Regional Blood Transfusion Centers (RCKiK), Military Blood Transfusion Center (WCKiK, supervised by the Ministry of Defense) and the Blood Transfusion Center of the Ministry of Internal Affairs and Administration (CKiK MSWiA, supervised by the Ministry of Internal Affairs and Administration). The Institute of Hematology and Transfusion Medicine (IHTM) has substantive supervision over the activity of all the above-mentioned entities of the public blood transfusion service.

This is our thirteenth presentation of selected issues related to the annual activities of the public blood transfusion service in Poland in the past year which takes into account the specific conditions caused by the COVID-19 pandemic. The following topics were discussed: the number of donors, the number of donations, the collection sites for whole blood and blood components, including red blood cell concentrate (RBC), fresh frozen plasma (FFP), platelet concentrate (PC) and granulocyte concentrate (GC) in 2020. We also discuss issues related to the use of some additional preparation methods as well as the inactivation of biological pathogens in labile blood components. The most common causes of the waste of blood components were explored as well as the degree of wastage.

\section{Materials and methods}

This work relies on the data provided by: $21 \mathrm{Re}-$ gional Blood Transfusion Centers (RCKiK), WCKiK, CKiK MSWiA in the form of annual activity reports for 2020. To the aim of standardization of the forwarded data, IHTM together with the National Blood Center (NCK) created a template of definitions.

First-time donor - donates blood during the reporting period but has never before donated blood for medical purposes.

Multiple (regular) donor - systematically donates blood (at least twice during the last 24 months).

Multiple repeat donor - donates blood again more than 2 years after the last donation.

Non remunerated donor - receives no financial compensation for donated blood/blood component at least once during the reporting period.

Remunerated donor - receives financial compensation for every donation during the reporting period.
Responder to donation appeal - donates blood /blood component following emergency appeal for donation at least once during the reporting period (the term also applies to former „family donors”).

Directed donor - donates blood for a specific patient at least once during the reporting period.

Autologous donor - donates blood/blood component for himself at least once during the reporting period.

Donation - whole blood or blood component collected by apheresis, including blood for clinical and scientific purposes collected from immunized and family donors etc.

Unit (u.) - volume of anticoagulated whole blood obtained from $450 \mathrm{ml}$ of blood collected from the donor or volume of blood component obtained from one unit of anticoagulated whole blood.

Unit of plasma - volume of plasma obtained from whole blood or by automated plasmapheresis. One automated plasmapheresis procedure provides 3 units of plasma $(600 \mathrm{ml})$.

Unit of PC from apheresis - platelets obtained from a single donor with cell separator ( 1 donation regardless of platelet count).

Therapeutic dose of $\mathrm{PC}-\mathrm{PCs}$ (either pooled or from apheresis) dedicated for an adult; according to current guidelines it contains $\geq 3 \times 10^{11}$ platelets.

\section{Results}

\section{Blood Transfusion Centers (Centers)}

In 2020, there were 23 Centers and 136 local collection sites operating in Poland. Moreover, 10,432 mobile collections were performed which is over $20 \%$ less than in the previous year. In 2020 mobile collections were organized by all RCKiK and WCKiK. As in the previous year, the largest number of mobile collections was organized by RCKiK in Katowice (1366). Over 1000 mobile collections were organized by RCKiK in Wałbrzych (1100) and Warsaw (1010). As compared to the previous year, the number of mobile collections decreased in $20 \mathrm{RCKiK}$ and WCKiK, and increased only in RCKiK in Białystok (Table 1).

\section{Donors}

In 2020 , a total of 653,467 persons came to donate blood (in 2019 - 719,627), but only some of them $(569,914)$ were qualified for donation (in 2019 - 614,579).

As in the previous years, blood or blood components for clinical use were donated by approximately $87 \%$ of the people who were willing to donate blood. The difference was mainly due to 
Table 1. Mobile collections organized in Polish Blood Transfusion Centers in 2019 and 2020

\begin{tabular}{|c|c|c|c|}
\hline \multirow[t]{2}{*}{ Center } & \multicolumn{3}{|c|}{ Mobile collections } \\
\hline & 2019 & 2020 & $\begin{array}{l}\text { Tendency (increase/decrease } \\
\text { compared to 2019) }\end{array}$ \\
\hline Białystok & 728 & 760 & $\uparrow$ \\
\hline Bydgoszcz & 872 & 718 & $\downarrow$ \\
\hline Gdańsk & 362 & 201 & $\downarrow$ \\
\hline Kalisz & 425 & 349 & $\downarrow$ \\
\hline Katowice & 1875 & 1366 & $\downarrow$ \\
\hline Kielce & 283 & 162 & $\downarrow$ \\
\hline Kraków & 793 & 508 & $\downarrow$ \\
\hline Lublin & 404 & 399 & $\downarrow$ \\
\hline Łódź & 1031 & 851 & $\downarrow$ \\
\hline Olsztyn & 494 & 421 & $\downarrow$ \\
\hline Opole & 229 & 131 & $\downarrow$ \\
\hline Poznań & 877 & 636 & $\downarrow$ \\
\hline Racibórz & 326 & 126 & $\downarrow$ \\
\hline Radom & 393 & 377 & $\downarrow$ \\
\hline Rzeszów & 229 & 229 & bz \\
\hline Słupsk & 159 & 108 & $\downarrow$ \\
\hline Szczecin & 422 & 342 & $\downarrow$ \\
\hline Wałbrzych & 1269 & 1100 & $\downarrow$ \\
\hline Warszawa & 1238 & 1010 & $\downarrow$ \\
\hline Wrocław & 371 & 237 & $\downarrow$ \\
\hline Zielona Góra & 268 & 186 & $\downarrow$ \\
\hline CKiK WCKiK & 463 & 215 & $\downarrow$ \\
\hline MSWiA & 0 & 0 & bz \\
\hline Total & 13511 & 10432 & $\downarrow$ \\
\hline
\end{tabular}

WCKiK - Military Blood Transfusion Center; CKiK MSWiA — Blood Transfusion Center of Internal Affairs and Administration $\downarrow$ decrease as compared to 2019; $\uparrow$ - increase as compared to 2019; bz — no change since 2019

donor deferral. In 2020, a total of 9537 permanent deferrals were applied. There were also 214,049 temporary deferrals of 176,854 people, and the most common cause $(65,892$ cases) was low hemoglobin level (like in the previous years). Temporary deferral was applied to 2,303 people for various reasons related to the ongoing COVID-19 pandemic (including disease, vaccinations, isolation).

Donors were mostly voluntary unremunerated $(569,566)$. In 2020 , blood and blood components were also donated by 25 remunerated donors and 323 autologous donors. In the number of voluntary donors, 50,012 were responders to appeal and 111 were directed donors.

In 17 Centers blood was donated only by voluntary unremunerated donors. The highest numbers of remunerated donors were reported by $\mathrm{RCKiK}$ in Gdańsk and Katowice (9 for each Center).
Among donors of blood and blood components there were 118,208 first-time donors $(20.74 \%)$, 367,459 multiple regular donors $(64.48 \%)$ and 84,247 multiple repeat donors (14.78\%).

22 Centers reported decrease in the number of donors, only in 1 (Lublin) - a slight increase was observed (by $0.19 \%$ ). Table 2 presents the number of donors in each Center in 2020.

As in the previous years, the most numerous group of blood donors were people aged 18 to 44 (a total of 479,636 including 138,576 women and 341,060 men).

\section{Donations}

In 2020, whole blood was collected most frequently $(1,105,434$ donations), while the least frequent were collections of: granulocyte concentrate ( 82 donations in $6 \mathrm{RCKiK}$ ) and aphe- 
Table 2. Blood donors in Polish Blood Transfusion Centers in 2020

\begin{tabular}{|c|c|c|c|c|c|}
\hline \multirow[t]{2}{*}{ Center } & \multicolumn{4}{|c|}{ Donors } & \multirow{2}{*}{$\begin{array}{c}\text { Increase/decrease } \\
\text { as compared } \\
\text { to } 2019\end{array}$} \\
\hline & First-time & Multiple-regular & Multiple repeat & Total & \\
\hline Białystok & 4301 & 20328 & 4234 & 28863 & $\downarrow$ \\
\hline Bydgoszcz & 6404 & 22060 & 4602 & 33066 & $\downarrow$ \\
\hline Gdańsk & 5251 & 17565 & 3905 & 26721 & $\downarrow$ \\
\hline Kalisz & 3809 & 13607 & 2885 & 20301 & $\downarrow$ \\
\hline Katowice & 8250 & 32047 & 5716 & 46013 & $\downarrow$ \\
\hline Kielce & 3667 & 9345 & 2419 & 15431 & $\downarrow$ \\
\hline Kraków & 9194 & 26990 & 6367 & 42551 & $\downarrow$ \\
\hline Lublin & 6784 & 17243 & 4309 & 28336 & $\uparrow$ \\
\hline Łódź & 8682 & 17786 & 6981 & 33449 & $\downarrow$ \\
\hline Olsztyn & 3546 & 12345 & 2562 & 18453 & $\downarrow$ \\
\hline Opole & 2068 & 8665 & 1276 & 12009 & $\downarrow$ \\
\hline Poznań & 7003 & 32630 & 6468 & 46101 & $\downarrow$ \\
\hline Racibórz & 2333 & 9104 & 1986 & 13423 & $\downarrow$ \\
\hline Radom & 2815 & 7310 & 1822 & 11947 & $\downarrow$ \\
\hline Rzeszów & 4885 & 19956 & 3294 & 28135 & $\downarrow$ \\
\hline Słupsk & 1727 & 5930 & 1038 & 8695 & $\downarrow$ \\
\hline Szczecin & 4760 & 14115 & 3022 & 21897 & $\downarrow$ \\
\hline Wałbrzych & 2312 & 7502 & 1241 & 11055 & $\downarrow$ \\
\hline Warszawa & 14241 & 33959 & 9294 & 57494 & $\downarrow$ \\
\hline Wrocław & 6917 & 22127 & 5178 & 34222 & $\downarrow$ \\
\hline Zielona Góra & 2798 & 7364 & 3567 & 13729 & $\downarrow$ \\
\hline WCKiK & 5488 & 7777 & 1977 & 15242 & $\downarrow$ \\
\hline CKiK MSWiA & 973 & 1704 & 104 & 2781 & $\downarrow$ \\
\hline Total & 118208 & 367459 & 84247 & 569914 & $\downarrow$ \\
\hline
\end{tabular}

WCKiK - Military Blood Transfusion Center; CKiK MSWiA — Blood Transfusion Center of Internal Affairs and Administration $\downarrow$ - decrease as compared to 2019; $\uparrow$ — increase as compared to 2019

resis $\mathrm{RBC}$ as the only component (16 donations in $3 \mathrm{RCKiK})$. As in previous years, the largest number of whole blood donations was reported by RCKiK in Warsaw $(102,724)$ and Katowice $(96,486)$. Apheresis was mainly used for preparation of PCs (12,997 donations) and plasma (55,421 donations). The largest numbers of apheresis plasma donations were reported by RCKiK in Kalisz $(9,496)$, and apheresis PC donations by RCKiK in Warsaw $(2,043)$.

Automated donations of a combination of blood components, mostly PC and plasma (27,040 donations - the majority in RCKiK) were also performed in Warsaw (8,602 donations), less frequently of $\mathrm{PC}$ and RBCs (282 donations) - almost exclusively at RCKiK in Wrocław (279 donations).

Table 3 presents the number of complete donations of blood and blood components in 2020 .
Blood was collected primarily in the local collection sites (46.84\% of whole blood donations), less frequently at the Center premises $(30.62 \%)$, and during mobile collections $(22.54 \%)$. As in previous years, the largest number of whole blood donations - $54.84 \%$ - took place during mobile collections organized by the RCKiK in Wałbrzych. Table 4 provides a list of whole blood collection sites in 2020.

\section{Blood components}

\section{Red blood cell concentrate}

Donated blood was processed into blood components, mostly RBC (a total of 1,089,978 units), which was a significant country-wide decrease as compared to the previous year (1,220,178 units). As in previous years, the largest amount of RBC 
Table 3. Whole blood and apheresis donations in 2020*

\begin{tabular}{|c|c|c|c|c|c|c|c|c|}
\hline \multirow[t]{2}{*}{ Center } & \multirow{2}{*}{$\begin{array}{l}\text { Whole } \\
\text { blood }\end{array}$} & \multicolumn{6}{|c|}{ Apheresis } & \multirow[t]{2}{*}{ Total } \\
\hline & & Plasma & RBC & PC & GC & $\mathrm{PC}+$ plasma & $\mathrm{PC}+\mathrm{RBC}$ & \\
\hline Białystok & 58964 & 7262 & 0 & 159 & 1 & 1964 & 0 & 68350 \\
\hline Bydgoszcz & 65015 & 6012 & 8 & 1091 & 11 & 56 & 0 & 72193 \\
\hline Gdańsk & 57156 & 2020 & 0 & 527 & 0 & 0 & 0 & 59703 \\
\hline Kalisz & 38900 & 9496 & 0 & 2 & 0 & 425 & 0 & 48823 \\
\hline Katowice & 96486 & 846 & 0 & 688 & 0 & 4345 & 0 & 102365 \\
\hline Kielce & 28010 & 1059 & 0 & 834 & 0 & 0 & 0 & 29903 \\
\hline Kraków & 86120 & 359 & 0 & 1903 & 48 & 0 & 0 & 88430 \\
\hline Lublin & 53464 & 5566 & 0 & 0 & 0 & 1760 & 0 & 60790 \\
\hline Łódź & 58907 & 961 & 0 & 1409 & 0 & 0 & 0 & 61277 \\
\hline Olsztyn & 36957 & 1686 & 0 & 211 & 0 & 476 & 0 & 39330 \\
\hline Opole & 26218 & 180 & 0 & 665 & 0 & 0 & 0 & 27063 \\
\hline Poznań & 83948 & 3620 & 0 & 234 & 0 & 1536 & 0 & 89338 \\
\hline Racibórz & 27415 & 2709 & 0 & 0 & 0 & 438 & 0 & 30562 \\
\hline Radom & 22108 & 2037 & 0 & 36 & 0 & 780 & 0 & 24961 \\
\hline Rzeszów & 59771 & 2829 & 0 & 1354 & 0 & 0 & 0 & 63954 \\
\hline Słupsk & 17722 & 987 & 3 & 19 & 0 & 220 & 3 & 18954 \\
\hline Szczecin & 42351 & 1515 & 0 & 55 & 4 & 1835 & 0 & 45760 \\
\hline Wałbrzych & 23082 & 336 & 0 & 74 & 0 & 38 & 0 & 23530 \\
\hline Warszawa & 102724 & 1518 & 0 & 2043 & 14 & 8602 & 0 & 114901 \\
\hline Wrocław & 61004 & 3985 & 5 & 1665 & 4 & 4546 & 279 & 71488 \\
\hline Zielona Góra & 29121 & 282 & 0 & 0 & 0 & 19 & 0 & 29422 \\
\hline WCKiK & 25649 & 17 & 0 & 16 & 0 & 0 & 0 & 25682 \\
\hline MSWiA & 4342 & 139 & 0 & 12 & 0 & 0 & 0 & 4493 \\
\hline Total & 1105434 & 55421 & 16 & 12997 & 82 & 27040 & 282 & 1201272 \\
\hline
\end{tabular}

WCKiK - Military Blood Transfusion Center; MSWiA — Blood Transfusion Center of Internal Affairs and Administration

*complete donations only

was obtained in RCKiK in Katowice and Warsaw (95,939 units and 102,509 units, respectively) (Table 5). A decrease in the number of RBC units was reported by all Centers.

Some part of RBC units was subjected to additional preparation the most common of which was leukocyte reduction and irradiation.

In 2020, a total of 229,197 units of leucocyte-depleted RBCs were obtained (21.03\% of all RBC units) and 107,377 units of leucocyte-depleted irradiated RBC (9.85\%). RBC irradiation alone was used sporadically, yielding 616 units of irradiated RBCs - $0.06 \%$ of all RBC units.

Country-wide, $30.88 \%$ of all RBCs were leukocyte-depleted and $9.91 \%$ of RBCs were irradiated. Table 6 presents the number of leukocyte-depleted and irradiated units of RBC prepared in Centers in 2020 .

\section{Platelet concentrate}

Platelet concentrate was the second most frequently prepared blood component, just like in the years before. Two basic methods were used for PC preparation:

- centrifugation of whole blood from traditional donations, and - if necessary - pooling several units of PC to obtain pooled PC. Some Centers used automated methods for obtaining PCs; - apheresis with cell separators (some of the PCs obtained with this method were divided into smaller therapeutic doses). Apheresis PCs from modern separators are leucocyte-depleted and require no additional elimination of leukocytes. In 2020 , a total of 77,485 pooled $\mathrm{PC}$ units were prepared (in $2019-82,283$ ), including 55,828 from buffy coat with manual method and 21,603 with automated methods. In the Center in Katowice, 
Table 4. Sites of whole blood collection in 2020

\begin{tabular}{|c|c|c|c|c|c|c|c|}
\hline \multirow[t]{3}{*}{ Center } & \multicolumn{7}{|c|}{ Whole blood collected (units)* } \\
\hline & \multicolumn{2}{|c|}{ Center site } & \multicolumn{2}{|c|}{ Local collection site } & \multicolumn{2}{|c|}{ Mobile collection site } & \multirow{2}{*}{$\begin{array}{c}\text { Total } \\
\text { J. }\end{array}$} \\
\hline & J. & $\%$ & J. & $\%$ & J. & $\%$ & \\
\hline Białystok & 13543 & 22.84 & 28698 & 48.39 & 17066 & 28.78 & 59307 \\
\hline Bydgoszcz & 16914 & 25.89 & 25611 & 39.20 & 22809 & 34.91 & 65334 \\
\hline Gdańsk & 19680 & 34.23 & 32664 & 56.82 & 5146 & 8.95 & 57490 \\
\hline Kalisz & 8482 & 21.80 & 14450 & 37.15 & 15969 & 41.05 & 38901 \\
\hline Katowice & 14741 & 15.02 & 57260 & 58.33 & 26169 & 26.66 & 98170 \\
\hline Kielce & 13961 & 49.60 & 8239 & 29.27 & 5945 & 21.12 & 28145 \\
\hline Kraków & 25190 & 29.00 & 47909 & 55.16 & 13753 & 15.83 & 86852 \\
\hline Lublin & 15048 & 27.83 & 28335 & 52.40 & 10692 & 19.77 & 54075 \\
\hline Łódź & 20904 & 34.96 & 21651 & 36.20 & 17247 & 28.84 & 59802 \\
\hline Olsztyn & 11429 & 30.59 & 16438 & 44.00 & 9492 & 25.41 & 37359 \\
\hline Opole & 6985 & 26.59 & 16088 & 61.23 & 3201 & 12.18 & 26274 \\
\hline Poznań & 28073 & 33.00 & 40348 & 47.43 & 16648 & 19.57 & 85069 \\
\hline Racibórz & 4395 & 15.92 & 19815 & 71.75 & 3405 & 12.33 & 27615 \\
\hline Radom & 11728 & 52.81 & 1557 & 7.01 & 8924 & 40.18 & 22209 \\
\hline Rzeszów & 15911 & 26.44 & 38335 & 63.71 & 5927 & 9.85 & 60173 \\
\hline Słupsk & 9901 & 55.20 & 5499 & 30.66 & 2538 & 14.15 & 17938 \\
\hline Szczecin & 18438 & 43.29 & 14931 & 35.06 & 9223 & 21.65 & 42592 \\
\hline Wałbrzych & 10528 & 45.16 & 0 & 0 & 12784 & 54.84 & 23312 \\
\hline Warszawa & 29833 & 28.70 & 46997 & 45.21 & 27122 & 26.09 & 103952 \\
\hline Wrocław & 30858 & 50.03 & 23649 & 38.34 & 7176 & 11.63 & 61683 \\
\hline Zielona Góra & 8554 & 29.04 & 15816 & 53.69 & 5090 & 17.28 & 29460 \\
\hline WCKiK & 2180 & 8.43 & 18452 & 71 & 5219 & 20.19 & 25851 \\
\hline MSWiA & 4381 & 100 & 0 & 0 & 0 & 0 & 4381 \\
\hline Total & 341657 & 30.62 & 522742 & 46.84 & 251545 & 22.54 & 1115944 \\
\hline
\end{tabular}

WCKiK - Military Blood Transfusion Center; MSWiA - Blood Transfusion Center of Internal Affairs and Administration

*incomplete donations included

54 units of PC from platelet-rich plasma were prepared.

In 2020, a total of 52,030 PCs were obtained by apheresis ( $40.17 \%$ of all units issued for clinical use (in $2019-53,503$, i.e. $39.4 \%$ ).

The highest number of PCs from whole blood was obtained in Katowice (10,054 pooled PC units) and Poznań (9,563 pooled PC units), while from apheresis - in Warsaw $(12,592)$.

The percentage of apheresis PCs differed significantly in Centers - from $0.67 \%$ in Zielona Góra to $80.41 \%$ in Warsaw and $88.41 \%$ in Białystok (Table 7).

Since 2020, only leukocyte-depleted PCs are issued for clinical use in Poland; some part of PC units are also irradiated. In 2020, a total of 71,845 therapeutic doses of leukocyte-depleted PCs were obtained which accounted for $55.47 \%$ of all obtained PCs, as well as 57,671 therapeutic doses of irradiated leukocyte-depleted PCs (44.53\%).

Table 8 presents the numbers of leukocyte-depleted and irradiated PCs obtained in Polish Centers in 2020.

In 2020, a total of 120,858 therapeutic doses of PCs were issued for clinical use (in 2015 114,163 , in $2016-118,391$, in $2017-123,668$, in $2018-127,049$, and in $2019-129,652$ ). After the upward trend observed for the several last years, a significant decline was recorded.

Some part of the obtained PCs were stored frozen.

In $2020,3.27 \%$ of all PCs were subjected to freezing (including $2.24 \%$ of pooled PCs, $5.18 \%$ of 
Table 5. Units of RBCs prepared in Polish Blood Transfusion Centers in 2020

\begin{tabular}{|c|c|c|}
\hline Center & RBCs & $\begin{array}{l}\text { Increase/decrease } \\
\text { compared to } 2019\end{array}$ \\
\hline Białystok & 57969 & $\downarrow$ \\
\hline Bydgoszcz & 64994 & $\downarrow$ \\
\hline Gdańsk & 56966 & $\downarrow$ \\
\hline Kalisz & 37063 & $\downarrow$ \\
\hline Katowice & 95939 & $\downarrow$ \\
\hline Kielce & 27956 & $\downarrow$ \\
\hline Kraków & 86014 & $\downarrow$ \\
\hline Lublin & 53390 & $\downarrow$ \\
\hline Łódź & 58396 & $\downarrow$ \\
\hline Olsztyn & 36870 & $\downarrow$ \\
\hline Opole & 26177 & $\downarrow$ \\
\hline Poznań & 81317 & $\downarrow$ \\
\hline Racibórz & 27195 & $\downarrow$ \\
\hline Radom & 21698 & $\downarrow$ \\
\hline Rzeszów & 57098 & $\downarrow$ \\
\hline Słupsk & 17726 & $\downarrow$ \\
\hline Szczecin & 42337 & $\downarrow$ \\
\hline Wałbrzych & 22952 & $\downarrow$ \\
\hline Warszawa & 102509 & $\downarrow$ \\
\hline Wrocław & 56684 & $\downarrow$ \\
\hline Zielona Góra & 28815 & $\downarrow$ \\
\hline WCKiK & 25573 & $\downarrow$ \\
\hline MSWiA & 4340 & $\downarrow$ \\
\hline Total & 1089978 & $\downarrow$ \\
\hline
\end{tabular}

WCKiK - Military Blood Transfusion Center; MSWiA — Blood Transfusion Center of Internal Affairs and Administration

$\downarrow$ - decrease as compared to 2019; $\uparrow$ — increase as compared to 2019

apheresis PCs). The summary also includes data from WCKiK and CKiK MSWIA, although in those Centers freezing of PCs is scarcely performed - in 2020 only 1 apheresis PC unit was frozen at the latter Center.

For the last several years, the percentage of frozen PCs has been observed to decrease; however, as compared to 2019 , a slight increase (by $0.04 \%$ ) has been recorded. There was a decrease in the percentage of frozen apheresis PCs (by $0.08 \%$ ) with a simultaneous increase in the percentage of pooled PCs (by $0.07 \%$ ). In consecutive years, the percentage of frozen PCs in individual Centers is on the same level. In 2020 however, there is a significant difference between individual Centers ranging from $0 \%$ in Białystok (no PC freezing), Kalisz and
Table 6. Leukocyte-depleted and irradiated RBCs prepared in Polish Centers in 2020

\begin{tabular}{|c|c|c|c|}
\hline Center & $\begin{array}{c}\text { Units } \\
\text { of leuko- } \\
\text {-depleted } \\
\text { RBCs }\end{array}$ & $\begin{array}{l}\text { Units of } \\
\text { itrradia- } \\
\text { ted RBCs }\end{array}$ & $\begin{array}{l}\text { Units of both } \\
\text { leuko-deplet- } \\
\text { ed and irradi- } \\
\text { ated RBCs }\end{array}$ \\
\hline Białystok & 2141 & 0 & 6417 \\
\hline Bydgoszcz & 3086 & 0 & 10440 \\
\hline Gdańsk & 1073 & 5 & 15314 \\
\hline Kalisz & 29114 & 0 & 94 \\
\hline Katowice & 32529 & 0 & 5190 \\
\hline Kielce & 5463 & 0 & 3330 \\
\hline Kraków & 7093 & 407 & 6665 \\
\hline Lublin & 1044 & 0 & 9236 \\
\hline Łódź & 12731 & 28 & 11607 \\
\hline Olsztyn & 4065 & 3 & 4386 \\
\hline Opole & 4234 & 0 & 592 \\
\hline Poznań & 17659 & 9 & 7385 \\
\hline Racibórz & 2789 & 0 & 35 \\
\hline Radom & 1704 & 0 & 56 \\
\hline Rzeszów & 328 & 69 & 6473 \\
\hline Słupsk & 1328 & 0 & 1490 \\
\hline Szczecin & 655 & 90 & 1906 \\
\hline Wałbrzych & 122 & 0 & 0 \\
\hline Warszawa & 85098 & 0 & 6356 \\
\hline Wrocław & 5167 & 5 & 8244 \\
\hline $\begin{array}{l}\text { Zielona } \\
\text { Góra }\end{array}$ & 5982 & 0 & 2160 \\
\hline WCKiK & 2722 & 0 & 0 \\
\hline MSWiA & 3071 & 0 & 0 \\
\hline Total & 229197 & 616 & 107377 \\
\hline
\end{tabular}

WCKiK - Military Blood Transfusion Center; MSWiA — Blood Transfusion Center of Internal Affairs and Administration

Poznań, to $14.8 \%$ in Slupsk (a decrease by $2.4 \%$ as compared to 2019), $18.8 \%$ in Wałbrzych (decrease by $0.6 \%$ ), $30.2 \%$ in Opole (increase by $5.5 \%$ ), $29.3 \%$ in Radom (decrease by $5.7 \%$ ) and $37.1 \%$ in Racibórz (increase by $2.9 \%$ ). In the Centers of Radom, Slupsk and Wałbrzych, the percentage of frozen PCs systematically decreases. As in the previous years, Racibórz reported the highest percentage of frozen pooled PCs (50.7\%, an increase by $7.7 \%)$. On the other hand, Zielona Góra, Slupsk and Radom reported the highest percentage of frozen apheresis PCs (56, 3\%; $51.7 \%$ and $34.4 \%$ respectively). At the same time, it should be noted that in Zielona Góra only 16 apheresis PCs were collected, 9 of which were frozen, hence such a high percentage of frozen PCs. 
Table 7. PCs from whole blood and apheresis (2020)

\begin{tabular}{|c|c|c|c|c|}
\hline \multirow[t]{2}{*}{ Center } & \multicolumn{4}{|c|}{ PC (therapeutic doses) } \\
\hline & $\begin{array}{l}\text { Pooled from whole } \\
\text { blood }\end{array}$ & Apheresis & Total & $\%$ of apheresis PCs \\
\hline Białystok & 555 & 4234 & 4789 & 88.41 \\
\hline Bydgoszcz & 7716 & 1467 & 9183 & 15.98 \\
\hline Gdańsk & 5654 & 745 & 6399 & 11.64 \\
\hline Kalisz & 1835 & 686 & 2521 & 27.21 \\
\hline Katowice & 10054 & 6584 & 16638 & 39.57 \\
\hline Kielce & 2919 & 932 & 3851 & 24.20 \\
\hline Kraków & 6868 & 2596 & 9464 & 27.43 \\
\hline Lublin & 4408 & 2132 & 6540 & 32.60 \\
\hline Łódź & 4139 & 1633 & 5772 & 28.29 \\
\hline Olsztyn & 3351 & 882 & 4233 & 20.84 \\
\hline Opole & 686 & 668 & 1354 & 49.34 \\
\hline Poznań & 9563 & 3451 & 13014 & 26.52 \\
\hline Racibórz & 479 & 529 & 1008 & 52.48 \\
\hline Radom & 380 & 849 & 1229 & 69.08 \\
\hline Rzeszów & 5266 & 1438 & 6704 & 21.45 \\
\hline Słupsk & 1434 & 259 & 1693 & 15.30 \\
\hline Szczecin & 2776 & 2053 & 4829 & 42.51 \\
\hline Wałbrzych & 1232 & 130 & 1362 & 9.54 \\
\hline Warszawa & 3067 & 12592 & 15659 & 80.41 \\
\hline Wrocław & 2599 & 8125 & 10724 & 75.76 \\
\hline Zielona Góra & 2356 & 16 & 2372 & 0.67 \\
\hline WCKiK & 69 & 16 & 85 & 18.82 \\
\hline MSWiA & 79 & 13 & 92 & 14.13 \\
\hline Total & 77485 & 52030 & 129515 & 40.17 \\
\hline
\end{tabular}

WCKiK - Military Blood Transfusion Center; MSWiA — Blood Transfusion Center of Internal Affairs and Administration

In 2020, thawed PCs accounted for $3.13 \%$ of all PC therapeutic doses issued for clinical use, i.e. $0.18 \%$ more than in 2019. The largest number of thawed PC units was reported by Racibórz (39.7\% of all PC units issued for clinical use), Radom (34, 3\%), Opole (26.4\%), Wałbrzych (18.1\%) and Slupsk (17.2\%). Centers in Kalisz, Poznań, CKiK MSWiA and WCKiK reported no issue of thawed PCs for clinical use.

\section{Fresh frozen plasma}

In 2020, a total of $1,264,654 \mathrm{FFP}$ units were prepared (in $2019-1,373,514$ units). As in the previous years, FFP was mainly obtained by manual method, i.e. plasma obtained from anticoagulated whole blood. With this method, 1,075,762 FFP units were obtained in 2020. On the other hand, with the less frequent method of apheresis 188,892 units were obtained, i.e. $14.94 \%$ of the total (in $2019-170,520$ units, i.e. $12.41 \%$ of the total). This is one of the very few examples of an upward trend observed in 2020 .

The percentage of FFP obtained by apheresis differed between Centers (the highest was reported by Kalisz $-44.01 \%$ ).

Table 9 presents the number of FFP units obtained by the manual method and by apheresis in individual Centers in 2020.

A total of 229,059 FFP units were issued for clinical use which is less than in 2019 (273,519 FFP units). As compared to the previous year, the number of FFP units issued for clinical use was lower in all Centers (Table 10). 
Table 8. Leukocyte-depleted and irradiated PCs prepared in Polish Centers in 2020

\begin{tabular}{|c|c|c|c|}
\hline Center & $\begin{array}{l}\text { PC the- } \\
\text { rapeutic } \\
\text { doses }\end{array}$ & $\begin{array}{l}\text { Leukocyte- } \\
\text {-depleted } \\
\text { PCs }\end{array}$ & $\begin{array}{l}\text { Irradiated } \\
\text { Leukocyte- } \\
\text { depleted } \\
\text { PCs }\end{array}$ \\
\hline Białystok & 4789 & 557 & 4232 \\
\hline Bydgoszcz & 9183 & 7805 & 1378 \\
\hline Gdańsk & 6399 & 453 & 5946 \\
\hline Kalisz & 2521 & 2519 & 2 \\
\hline Katowice & 16638 & 11105 & 5533 \\
\hline Kielce & 3851 & 1861 & 1990 \\
\hline Kraków & 9464 & 4427 & 5037 \\
\hline Lublin & 6540 & 423 & 6117 \\
\hline Łódź & 5772 & 4677 & 1095 \\
\hline Olsztyn & 4233 & 484.2 & 3749 \\
\hline Opole & 1354 & 1211 & 143 \\
\hline Poznań & 13014 & 4364 & 8650 \\
\hline Racibórz & 1008 & 993 & 15 \\
\hline Radom & 1229 & 1224 & 5 \\
\hline Rzeszów & 6704 & 5674 & 1030 \\
\hline Słupsk & 1693 & 677 & 1016 \\
\hline Szczecin & 4829 & 2355 & 2474 \\
\hline Wałbrzych & 1362 & 1362 & 0 \\
\hline Warszawa & 15659 & 15633 & 26 \\
\hline Wrocław & 10724 & 2225 & 8499 \\
\hline $\begin{array}{l}\text { Zielona } \\
\text { Góra }\end{array}$ & 2372 & 1638 & 734 \\
\hline WCKiK & 85 & 85 & 0 \\
\hline MSWiA & 92 & 92 & 0 \\
\hline Total & 129514 & 71845 & 57671 \\
\hline
\end{tabular}

WCKiK - Military Blood Transfusion Center; MSWiA — Blood Transfusion Center of Internal Affairs and Administration

\section{COVID-19 convalescent plasma}

The outbreak of COVID-19 pandemic announced by WHO in March 2020, has burdened the Polish blood transfusion service with the additional task of collecting convalescent plasma. In 2020, a total of 57708 units of convalescent plasma were collected, 25,868 units of which (44.83\%) were issued for clinical purposes.

Convalescent plasma was collected by all Centers; the highest volumes were reported by the Centers in Warsaw and Bydgoszcz (5094 and 5644, respectively). Table 11 presents the numbers of convalescent plasma units obtained from COVD-19 convalescents and issued for clinical purposes by individual Centers in 2020.

\section{Granulocyte concentrate}

As in previous years, in 2020, granulocyte concentrate (GC) was only sporadically obtained (82 donations in 6 Centers), i.e. less frequently than in 2019 (94 donations) and 2018 (116 donations). Most GC donations took place in Kraków (48) and Warsaw (14).

\section{Quarantine and inactivation of biological pathogens in labile blood components}

In Poland we rely solely on quarantine ${ }^{1}$ or pathogen inactivated FFP and cryoprecipitate with the aim of ensuring the safety of transfused blood components. Currently there are three (3) pathogen inactivation systems implemented in the Polish Blood Transfusion Centers : Theraflex MB Plasma (with methylene blue) for pathogen inactivation in plasma, Mirasol PRT (with riboflavin) and Intercept (with amotosalen hydrochloride) for pathogen inactivation in plasma and PC. Some methods of inactivation (Mirasol PRT and Intercept) do not only minimize the risk of pathogen transmission but may also serve as alternative to irradiation of cellular blood components used for prevention of transfusion-associated Graft Versus Host Disease (TA-GvHD). PCs already subjected to pathogen inactivation with one of these PRT systems do not need to be subjected to irradiation [2-4].

In 2020, pathogen inactivation technology (PRT) was used by 23 Centers. The following systems were used:

- Mirasol in 16 Centers (in 14 regional Centers, WCKiK and CKiK MSWiA);

- Theraflex MB Plasma (in 10 regional Centers);

- Intercept (in 4 regional Centers; Białystok applied inactivation solely for validation purposes -25 units of apheresis plasma were subjected to inactivation).

The percentage of plasma subjected to inactivation ranged from $0.02 \%$ (Center in Szczecin) to $12.50 \%$ (Center in Poznań). Countrywide, a total of $3.01 \%$ of all plasma was subjected to inactivation. COVID-19 convalescent plasma was also subjected to inactivation and the values ranged from $27.93 \%$ in Lublin to $100 \%$ in Poznań, WCKiK and CKiK MSWiA (63.36\% countrywide).

A total of $85.92 \%$ of quarantine FFP and $93.11 \%$ of quarantine cryoprecipitate were issued for clinical use as well as $14.21 \%$ of pathogen inactivated FFP units and $6.89 \%$ of pathogen inactivated cryoprecipitate (cryoprecipitate in Poznań only).

Inactivation of pooled PCs was implemented in 7 Centers, (6 used the Mirasol system, 1 used

Quarantine of FFP and cryoprecipitate consists in storage for at least 16 weeks of donation date followed by testing the donor for infectious disease markers (to eliminate the diagnostic window period). 
Table 9. FFP (from whole blood and apheresis) prepared in Polish Blood Transfusion Centers in 2020

\begin{tabular}{|c|c|c|c|c|}
\hline Center & Whole blood (manual method) & Apheresis & Total & $\%$ apheresis FFP \\
\hline Białystok & 57943 & 29749 & 87692 & 33.92 \\
\hline Bydgoszcz & 64551 & 17805 & 82356 & 21.62 \\
\hline Gdańsk & 56506 & 4160 & 60666 & 6.86 \\
\hline Kalisz & 37064 & 29138 & 66202 & 44.01 \\
\hline Katowice & 95939 & 6821 & 102760 & 6.64 \\
\hline Kielce & 27662 & 1960 & 29622 & 6.62 \\
\hline Kraków & 86035 & 1094 & 87129 & 1.26 \\
\hline Lublin & 51350 & 15079 & 66429 & 22.70 \\
\hline Łódź & 58396 & 3182 & 61578 & 5.17 \\
\hline Olsztyn & 35064 & 3891 & 38955 & 9.99 \\
\hline Opole & 26075 & 49 & 26124 & 0.19 \\
\hline Poznań & 80985 & 10823 & 91808 & 11.79 \\
\hline Racibórz & 27193 & 5029 & 32222 & 15.61 \\
\hline Radom & 21557 & 5611 & 27168 & 20.65 \\
\hline Rzeszów & 57098 & 8464 & 65562 & 12.91 \\
\hline Słupsk & 17723 & 2422 & 20145 & 12.02 \\
\hline Szczecin & 42337 & 7240 & 49577 & 14.60 \\
\hline Wałbrzych & 22132 & 941 & 23073 & 4.08 \\
\hline Warszawa & 102509 & 13079 & 115588 & 11.32 \\
\hline Wrocław & 56317 & 21174 & 77491 & 27.32 \\
\hline Zielona Góra & 29064 & 777 & 29841 & 2.60 \\
\hline WCKiK & 18029 & 51 & 18080 & 0.28 \\
\hline MSWiA & 4233 & 355 & 4588 & 7.74 \\
\hline Total & 1075762 & 188892 & 1264654 & 14.94 \\
\hline
\end{tabular}

WCKiK - Military Blood Transfusion Center; MSWiA — Blood Transfusion Center of Internal Affairs and Administration

Intercept). The percentage of pooled PCs subjected to inactivation ranged from $0.04 \%$ (Center in Rzeszów) to $100.00 \%$ (Center in Warsaw). Countrywide, this accounted for $5.18 \%$ of all pooled PC units.

11 Centers inactivated apheresis PCs (10 used Mirasol, 1 used Intercept). The percentage of inactivated apheresis PCs ranged from $0.05 \%$ (in Białystok) to $98.13 \%$ (in Warsaw). Countrywide, this accounted for $26.19 \%$ of all apheresis PC units. In 2020, a total of $11.01 \%$ of inactivated PC therapeutic units were issued for clinical use.

Table 12 presents the 2020-percentage of pathogen inactivated FFP units, pooled PCs and apheresis PCs issued for clinical use.

The percentage of convalescent plasma subjected to pathogen inactivation in 2020 is presented in Tabele 13.

The percentage of FFP, cryoprecipitate and PC therapeutic units issued for clinical use follo- wing pathogen inactivation in 2020 is presented in Tabele 14.

\section{Wastage of blood and blood components}

In 2020, a total of 103,433 units of blood and most common blood components were wasted, including 11,430 units of anticoagulated whole blood, 29,530 units of RBCs, 53,946 units of FFP, 1,691 therapeutic units of apheresis PCs, 5,455 units of pooled PCs from whole blood, as well as 1,381 units of cryoprecipitate.

As in the previous years, the most common reasons for wastage of blood components were:

1. Expiry date;

2. Seropositivity for transfusion transmitted diseases, syphilis tests, implementation of look-back procedure;

3. Other causes, including:

- inadequate visual control; 
Table 10. FFP issued for clinical use in Polish Blood Transfusion Centers in 2020 (convalescent plasma not included)

\begin{tabular}{lcc}
\hline Center & $\begin{array}{c}\text { FFP issued } \\
\text { for clinical use } \\
\text { (units) }\end{array}$ & $\begin{array}{c}\text { Tendency (increase/ } \\
\text { /decrease compa- } \\
\text { red to 2019) }\end{array}$ \\
\hline Białystok & 11042 & $\downarrow$ \\
Bydgoszcz & 14888 & $\downarrow$ \\
Gdańsk & 8182 & $\downarrow$ \\
Kalisz & 3500 & $\downarrow$ \\
Katowice & 21222 & $\downarrow$ \\
Kielce & 5447 & $\downarrow$ \\
Kraków & 19236 & $\downarrow$ \\
Lublin & 13319 & $\downarrow$ \\
tódź & 14072 & $\downarrow$ \\
Olsztyn & 6561 & $\downarrow$ \\
Opole & 4007 & $\downarrow$ \\
Poznań & 15195 & $\downarrow$ \\
Racibórz & 2305 & $\downarrow$ \\
Radom & 2065 & $\downarrow$ \\
Rzeszów & 10011 & $\downarrow$ \\
Słupsk & 2425 & $\downarrow$ \\
Szczecin & 12850 & $\downarrow$ \\
Wałbrzych & 4878 & $\downarrow$ \\
Warszawa & 35607 & $\downarrow$ \\
Wrocław & 7056 & $\downarrow$ \\
Zielona Góra & 5405 & $\downarrow$ \\
WCKik & 7568 & $\downarrow$ \\
MSWiA & 2217 & $\downarrow$ \\
Total & 229059 & $\downarrow$ \\
\hline CKK & $\downarrow$ & $\downarrow$ \\
\hline
\end{tabular}

WCKiK - Military Blood Transfusion Center; MSWiA — Blood Transfusion Center of Internal Affairs and Administration

$\downarrow$ - decrease as compared to 2019; $\uparrow$ - increase as compared to 2019

- low quantity/volume;

- seropositive serological results;

- other, including incorrect procedures, medical deferral, mechanical damage, donor self-deferral etc.

Subjected to wastage were also blood components from autologous donations that were not put to clinical use.

Table 15 presents the number of blood components wasted in individual Centers in 2020; causes of waste are shown in Table 16.

\section{Discussion}

In many ways, 2020 was a very special year as it was the first year of the announced COVID-19
Table 11. Convalescent plasma issued for clinical use by Polish Blood Transfusion Centers in 2020

\begin{tabular}{|c|c|c|c|}
\hline Center & $\begin{array}{l}\text { Convale- } \\
\text { scent } \\
\text { plasma } \\
\text { (units) }\end{array}$ & $\begin{array}{l}\text { Issued } \\
\text { for clinical } \\
\text { use (units) }\end{array}$ & $\begin{array}{c}\% \text { of plasma } \\
\text { used for } \\
\text { clinical } \\
\text { purposes }\end{array}$ \\
\hline Białystok & 2369 & 1779 & 75.10 \\
\hline Bydgoszcz & 5644 & 3136 & 55.57 \\
\hline Gdańsk & 2601 & 1333 & 51.25 \\
\hline Kalisz & 1875 & 870 & 46.40 \\
\hline Katowice & 3249 & 1599 & 49.22 \\
\hline Kielce & 1472 & 743 & 50.48 \\
\hline Kraków & 3184 & 1267 & 39.78 \\
\hline Lublin & 5539 & 1929 & 34.82 \\
\hline Łódź & 2665 & 1036 & 38.87 \\
\hline Olsztyn & 1998 & 1113 & 55.71 \\
\hline Opole & 632 & 365 & 57.74 \\
\hline Poznań & 3010 & 1604 & 53.29 \\
\hline Racibórz & 3705 & 1302 & 35.14 \\
\hline Radom & 1938 & 879 & 45.36 \\
\hline Rzeszów & 3060 & 749 & 24.48 \\
\hline Słupsk & 861 & 234 & 27.18 \\
\hline Szczecin & 2271 & 609 & 26.82 \\
\hline Wałbrzych & 713 & 690 & 96,77 \\
\hline Warszawa & 5094 & 2003 & 39,32 \\
\hline Wrocław & 4573 & 1789 & 39.12 \\
\hline $\begin{array}{l}\text { Zielona } \\
\text { Góra }\end{array}$ & 849 & 457 & 53.83 \\
\hline WCKiK & 51 & 33 & 64.71 \\
\hline MSWiA & 355 & 350 & 98.59 \\
\hline Total & 57708 & 25868 & 44.83 \\
\hline
\end{tabular}

WCKiK - Military Blood Transfusion Center; MSWiA — Blood Transfusion Center of Internal Affairs and Administration

pandemic. In the section "Current problems of blood donation and transfusion medicine" we present some pandemic-related circumstances and the implications they may have regarding blood donation. Regardless of the circumstances however, the basic factor that determines the availability of blood supply is still the good will, and thus - a sufficient number of volunteer, non-remunerated blood donors [5-9].

In line with the observations presented above, in 2020 the number of donors in the Centers in Poland - 569,914 — was the lowest in several last years $(614,579$ in $2019,614,570$ in 2018).

One factor that contributes to the decline in the number of blood donors observed in the recent years is the decrease in population in the $18-65$ age 
Table 12. Percentage of pathogen inactivated units of FFP, pooled PCs and apheresis PCs prepared in Centers (2020)

\begin{tabular}{|c|c|c|c|c|}
\hline Center & FFP (\%) & Pooled PCs (\%) & Apheresis PCs (\%) & Systems \\
\hline Białystok & 0.84 & 0.00 & 0.05 & Mirasol, Theraflex \\
\hline Bydgoszcz & 1.82 & 0.00 & 0.00 & Mirasol, Theraflex \\
\hline Gdańsk & 0.61 & 0.00 & 0.00 & Mirasol \\
\hline Kalisz & 0.00 & 0.00 & 0.00 & Theraflex \\
\hline Katowice & 1.03 & 1.26 & 1.37 & Mirasol \\
\hline Kielce & 0.12 & 0.00 & 16.63 & Mirasol, \\
\hline Kraków & 8.44 & 0.23 & 0.32 & Mirasol \\
\hline Lublin & 0.73 & 0.00 & 0.00 & Mirasol, Theraflex \\
\hline Łódź & 3.90 & 3.77 & 10.73 & Mirasol \\
\hline Olsztyn & 0.00 & 0.00 & 0.00 & Theraflex \\
\hline Opole & 0.03 & 0.00 & 0.00 & Theraflex \\
\hline Poznań & 12.50 & 0.00 & 0.00 & Theraflex \\
\hline Racibórz & 0.91 & 0.00 & 0.00 & Theraflex \\
\hline Radom & 0.00 & 0.00 & 42.17 & Mirasol, Intercept \\
\hline Rzeszów & 1.15 & 0.04 & 0.30 & $\begin{array}{l}\text { Mirasol } \\
\text { Theraflex }\end{array}$ \\
\hline Słupsk & 0.00 & 0.00 & 0.00 & Mirasol \\
\hline Szczecin & 0.02 & 0.00 & 0.00 & Mirasol, Intercept \\
\hline Wałbrzych & 2.66 & 0.00 & 0.00 & Mirasol \\
\hline Warszawa & 6.83 & 100.00 & 98.13 & Intercept \\
\hline Wrocław & 2.50 & 0.00 & 0.55 & Mirasol \\
\hline Zielona Góra & 0.39 & 0.00 & 0.00 & Theraflex \\
\hline WCKiK & 3.79 & 42.47 & 25.00 & Mirasol \\
\hline MSWiA & 11.90 & 12.66 & 61.54 & Mirasol \\
\hline Total & 3.01 & 5.18 & 26.19 & \\
\hline
\end{tabular}

WCKiK - Military Blood Transfusion Center; MSWiA — Blood Transfusion Center of Internal Affairs and Administration

group - the potential "recruitment source" of blood donors. According to the data provided by the Demographic Yearbook reports (Central Statistical Office of Poland) for 31 December 2011 this number was estimated at $26,460,477$, while for 31 December 2020 - only 24,689,690 [10, 11]. During this period (2011-2020), the population in the above-mentioned age group decreased by almost two million, which may impact negatively on the number of active blood donors.

In the member states of the Council of Europe, the average number of blood donors per 1,000 inhabitants decreased in the period 2008-2011 from 29.0 to 25.0 [12]. In Poland, in 2020, the numbers per 1000 inhabitants were 14.42 (in $2019-15.39$, $2018-15.37$, and in $2017-15.30$ ).

Moreover, both in Poland and in other countries, there is a downward trend in the number of people declaring their willingness to donate blood; this is especially true for certain age groups. In Po- land, such a tendency can be observed especially in the 18-24 age group i.e. a group of potential donors of blood and blood components in the future [13]. Apart from the above-mentioned demographic changes, the number of blood donors is adversely affected by factors such as:

- periodic disease outbreaks - eg. COVID-19 pandemic;

- travel-associated risk of infection e.g. malaria or West Nile virus [14-16];

- emerging infectious diseases (other than COVID-19) e.g. the epidemic of Zika virus infections [17, 18];

- health condition of the population, including reduced hemoglobin levels (the most common cause of deferrals in the last years) [19-21];

- no opportunity to donate blood or economic reasons.

The number of autologous donors has been low in the recent years. In 2020, it was estimated at 
Table 13. COVD-19 convalescent plasma - percentage subjected to pathogen inactivation in Centers (2020)

\begin{tabular}{|c|c|c|c|}
\hline Center & $\begin{array}{c}\text { Convale- } \\
\text { scent } \\
\text { plasma } \\
\text { (units) }\end{array}$ & $\begin{array}{l}\text { Convale- } \\
\text { scent } \\
\text { plasma) } \\
\text { subjected } \\
\text { to pathogen } \\
\text { inactivation } \\
\text { (units) }\end{array}$ & $\begin{array}{l}\text { Percentage } \\
\text { of plasma } \\
\text { subjected } \\
\text { to pathogen } \\
\text { inactivation }\end{array}$ \\
\hline Białystok & 2369 & 2170 & 91.58 \\
\hline Bydgoszcz & 5644 & 3790 & 67.15 \\
\hline Gdańsk & 2601 & 1613 & 62.01 \\
\hline Kalisz & 1875 & 1265 & 67.47 \\
\hline Katowice & 3249 & 2671 & 82.21 \\
\hline Kielce & 1472 & 935 & 63.52 \\
\hline Kraków & 3184 & 2592 & 81.41 \\
\hline Lublin & 5539 & 1547 & 27.93 \\
\hline Łódź & 2665 & 1471 & 55.20 \\
\hline Olsztyn & 1998 & 1808 & 90.49 \\
\hline Opole & 632 & 561 & 88.71 \\
\hline Poznań & 3010 & 3010 & 100.00 \\
\hline Racibórz & 3705 & 1209 & 32.63 \\
\hline Radom & 1938 & 875 & 45.15 \\
\hline Rzeszów & 3060 & 1907 & 62.32 \\
\hline Słupsk & 861 & 244 & 28.34 \\
\hline Szczecin & 2271 & 1232 & 54.23 \\
\hline Wałbrzych & 713 & 514 & 72.09 \\
\hline Warszawa & 5094 & 3859 & 75.76 \\
\hline Wrocław & 4573 & 2272 & 49.67 \\
\hline $\begin{array}{l}\text { Zielona } \\
\text { Góra }\end{array}$ & 849 & 616 & 72.56 \\
\hline WCKiK & 51.0 & 51 & 100.00 \\
\hline MSWiA & 355.0 & 355 & 100.00 \\
\hline Total & 57708 & 36565 & 63.36 \\
\hline
\end{tabular}

WCKiK - Military Blood Transfusion Center; MSWiA — Blood Transfusion Center of Internal Affairs and Administration

323 , i.e. the lowest number in the last several years (in 2019 - 630, in 2018 - 598, in 2017 - 692). The smaller number of preoperative autologous donations is a phenomenon observed in many countries [22]. In line with current recommendations, autologous donations are mostly relied on when they have significant advantage over allogenic transfusions, and when indications for transfusion are strong. Autologous donations are useful primarily in cases when compatible allogenic blood is unavailable, eg. when the patient has antibodies against antigens with high prevalence in population [23].
Tabele 14. Percentage of pathogen inactivated FFP, cryoprecipitate and PC units issued for clinical use in 2020

\begin{tabular}{lccc}
\hline Center & $\begin{array}{c}\text { \% FFP } \\
\text { (units) }\end{array}$ & $\begin{array}{c}\text { \% Cryopreci- } \\
\text { pitate (units) }\end{array}$ & $\begin{array}{c}\% \text { PC } \\
\text { (therapeutic } \\
\text { units) }\end{array}$ \\
\hline Białystok & 5.35 & 0 & 0.04 \\
Bydgoszcz & 8.61 & 0 & 0.00 \\
Gdańsk & 1.91 & 0 & 0.00 \\
Kalisz & 0.06 & 0 & 0.00 \\
Katowice & 2.54 & 0 & 1.32 \\
Kielce & 0.00 & 0 & 5.47 \\
Kraków & 23.64 & 0 & 0.27 \\
Lublin & 1.85 & 0 & 0.00 \\
Łódź & 15.47 & 0 & 6.12 \\
Olsztyn & 1.68 & 0 & 0.00 \\
Opole & 0.17 & 0 & 0.00 \\
Poznań & 41.03 & 100 & 0.00 \\
Racibórz & 25.46 & 0 & 0.00 \\
Radom & 0.00 & 0 & 31.16 \\
Rzeszów & 8.91 & 0 & 0.08 \\
Słupsk & 0.00 & 0 & 0.00 \\
Szczecin & 0.00 & 0 & 0.00 \\
Wałbrzych & 0.00 & 0 & 0.00 \\
Warszawa & 33.88 & 0 & 92.78 \\
Wrocław & 18.33 & 0 & 0.36 \\
Zielona Góra & 0.00 & 0 & 0 \\
WCKiK & 0.98 & 0 & 11.76 \\
MSWiA & 12.81 & 0 & 29.58 \\
Total & 14.21 & 6.89 & 11.01 \\
\hline WCKi-Ming & 0 & 0.00 \\
\hline
\end{tabular}

WCKiK - Military Blood Transfusion Center; MSWiA — Blood Transfusion Center of Internal Affairs and Administration

In 2020, the total number of blood and blood component donations amounted to $1,201,272$, including $1,105,434$ whole blood donations; a decrease compared to the previous year (in $2019-1,331,447$ donations and 1,242,012 whole blood donations, respectively).

One of the methods used for more effective collection of blood components is automated apheresis. In 2020, the number of apheresis PCs and plasma donations combined decreased as compared to 2019 (from 28,966 to 27,040 ), and so did the number of PC donations only (from 17,858 to 12,997 ). On the other hand, there was an increase in the number of plasma donations only (from 42,386 to 55,421 ). Collection by apheresis of other blood components, ie RBCs and granulocyte concentrate (GC) was sporadic. 
Table 15. Wastage of blood components in Polish Blood Transfusion Centers in 2020

\begin{tabular}{|c|c|c|c|c|c|c|}
\hline \multirow[t]{2}{*}{ Center } & \multirow{2}{*}{$\begin{array}{l}\text { Whole } \\
\text { blood }\end{array}$} & \multirow[t]{2}{*}{ RBCs } & \multicolumn{2}{|l|}{ KKP (packages) } & \multirow[t]{2}{*}{ FFP } & \multirow{2}{*}{$\begin{array}{l}\text { Cryoprecipi- } \\
\text { tate }\end{array}$} \\
\hline & & & Pooled (from whole blood) & Apheresis & & \\
\hline Białystok & 171 & 448 & 1 & 27 & 828 & 66 \\
\hline Bydgoszcz & 25 & 50 & 54 & 0 & 356 & 22 \\
\hline Gdańsk & 223 & 1176 & 376 & 19 & 2175 & 107 \\
\hline Kalisz & 144 & 990 & 195 & 12 & 1171 & 39 \\
\hline Katowice & 805 & 2459 & 400 & 184 & 3161 & 89 \\
\hline Kielcach & 53 & 815 & 732 & 51 & 1400 & 37 \\
\hline Kraków & 744 & 1475 & 178 & 41 & 6613 & 80 \\
\hline Lublin & 87 & 1767 & 171 & 94 & 2195 & 16 \\
\hline Łódź & 1339 & 2628 & 255 & 99 & 3449 & 83 \\
\hline Olsztyn & 87 & 742 & 194 & 62 & 806 & 112 \\
\hline Opole & 72 & 761 & 24 & 21 & 929 & 0 \\
\hline Poznań & 1151 & 3443 & 1029 & 99 & 2997 & 18 \\
\hline Racibórz & 122 & 1134 & 45 & 22 & 542 & 0 \\
\hline Radom & 507 & 1194 & 151 & 103 & 1072 & 89 \\
\hline Rzeszów & 2685 & 1791 & 521 & 46 & 1621 & 67 \\
\hline Słupsk & 0 & 245 & 154 & 16 & 668 & 2 \\
\hline Szczecin & 161 & 1394 & 251 & 111 & 2322 & 37 \\
\hline Wałbrzych & 249 & 555 & 125 & 11 & 213 & 0 \\
\hline Warszawa & 1421 & 2366 & 159 & 540 & 7792 & 176 \\
\hline Wrocław & 688 & 1645 & 124 & 120 & 1939 & 50 \\
\hline Zielona Góra & 397 & 902 & 285 & 3 & 640 & 1 \\
\hline WCKiK & 257 & 1434 & 6 & 10 & 8101 & 290 \\
\hline MSWiA & 41 & 117 & 25 & 0 & 2959 & 0 \\
\hline Total & 11430 & 29530 & 5455 & 1691 & 53946 & 1381 \\
\hline
\end{tabular}

WCKiK - Military Blood Transfusion Center; MSWiA - Blood Transfusion Center of Internal Affairs and Administration

Table 16. Reasons for blood component wastage in Polish Blood Transfusion Centers in 2020

\begin{tabular}{|c|c|c|c|c|c|c|}
\hline Reason & $\begin{array}{l}\text { Whole } \\
\text { blood }\end{array}$ & RBCs & $\begin{array}{l}\text { PC therapeutic } \\
\text { doses pooled } \\
\text { from whole } \\
\text { blood }\end{array}$ & $\begin{array}{l}\text { PC therapeutic } \\
\text { doses from } \\
\text { apheresis }\end{array}$ & FFP & $\begin{array}{l}\text { Cryopre- } \\
\text { cipitate }\end{array}$ \\
\hline Expiry date & 0 & 11586 & 3730 & 606 & 10847 & 44 \\
\hline $\begin{array}{l}\text { Seropositive for transfusion trans- } \\
\text { mitted diseases, syphilis tests, } \\
\text { implementation of look-back pro- } \\
\text { cedure }\end{array}$ & 29 & 2110 & 204 & 48 & 3260 & 12 \\
\hline $\begin{array}{l}\text { Other causes, including: } \\
\text { inadequate visual control } \\
\text { low quantity/volume } \\
\text { seropositive serological results, } \\
\text { other, including incorrect proce- } \\
\text { dures, medical deferral, mechanical } \\
\text { damage, donor self-deferral etc. }\end{array}$ & 11400 & 15967 & 1521 & 1037 & 39654 & 1325 \\
\hline $\begin{array}{l}\text { Unused blood components from } \\
\text { autologous donations }\end{array}$ & 3 & 102 & & & 186 & \\
\hline Total & 11432 & 29765 & 5455 & 1691 & 53947 & 1381 \\
\hline
\end{tabular}


It should be noted that automated methods (apheresis) are still used in Poland to a relatively small extent, in 2020 - only $8 \%$ of all donations.

Mobile collections are organized to make blood donation easier for donors. In 2020, the Centers organized 10,432 mobile teams which is significantly less than in the previous year $(13,511)$. The percentage of whole blood donations collected by mobile teams was also relatively small $-22.69 \%$. In 2020 , blood was mainly collected at local collection sites $-46.84 \%$ of all whole blood donations. This may be explained by the fact that donors are more willing to donate in familiar places. However, the contemporary high standards for collection of blood dedicated for clinical use do not favor small collection sites; centralization of blood transfusion service is recommended.

The demand for blood components is influenced by a number of factors, including current guidelines issued by scientific societies, profile of the clinical ward and recommendations of the physician. No doubt, the COVID-19 pandemic had strong impact on the activity of hospitals, and on the use of blood components.

In 2020, approximately 27.87 units of RBCs per 1,000 inhabitants were issued for clinical purposes (in $2019-30.7$ units, in $2018-30.38$ units, in $2017-30.22$ units, $2016-29.99,2015$ - 29.87) [11, 24-28]. The upward trend in RBC consumption observed in the previous years has changed and the RBC consumption in 2020 decreased. The RBC consumption in Poland has for years been lower than in some other European countries - for example, in 2011 the RBC consumption in 32 member states of the Council of Europe was on average 37 units/1,000 inhabitants [12].

In 2020 the number of FFP units issued for clinical purposes amounted to 229,059 units and was lower than in the previous year (273,519 units). On the other hand, the ratio of RBC for clinical use to FFP was approximately 4.57 (in $2019-4.31$, in $2018-4.09$, in $2017-3.77$, in $2016-3.56$, in 2015 - 3.45), so the upward trend continues [29-33]. These observations indicate that the consumption of FFP gradually declines as compared to $\mathrm{RBC}$ consumption. However, the $\mathrm{RBC} / \mathrm{FFP}$ ratio is still higher than in many European countries [12]. This may be explained by the lower consumption of $\mathrm{RBC}$ in Poland - as mentioned above, but in many cases also by the fact that FFP is used for no sufficient justification and sometimes against currently restrictive indications [34, 35].

The last several years have witnessed the increase in the consumption of PC. In the period
2015-2019, the number of PC therapeutic units issued for clinical use increased from 114,163 to 129,652 (more than 13\%). A similar phenomenon was observed in other countries [36]. In 2020 however, only 120,858 therapeutic units of PC were issued for clinical purposes, so also in this case the decline is obvious.

Additional preparation methods (leukocyte depletion, irradiation) for prevention of transfusion associated adverse reactions were applied mainly to PCs (55.47\% leukocyte depleted PCs and $44.53 \%$ of irradiated leukocyte depleted PCs), less often to RBC (21.03\% of leukocyte depleted RBCs, $9.85 \%$ irradiated leukocyte depleted $\mathrm{RBC}$ and $0.06 \%$ irradiated $\mathrm{RBCs})$. As already mentioned above, since 2020, only leucocyte-depleted PCs are issued for clinical use in Poland. Moreover, leucocyte-depleted $\mathrm{RBCs}$ require additional preparation, while in the case of apheresis PCs leukodepletion may occur at collection.

Some automated methods of PC preparation from the buffy coat also allow for the simultaneous elimination of leukocytes, but the cost of such preparation is still relatively high as compared to manual methods. Automated methods do however guarantee higher quality parameters due to standardization.

Regular/common leuko-depletion is now implemented in many countries, although its effectiveness for prevention of transfusion related adverse reactions is sometimes questioned [37].

As in the previous years, the number of frozen PCs in some Centers is too high. As mentioned above, in 2020 no decrease in the percentage of frozen PCs was reported which may be related to the COVID 19 pandemic. The percentage reported for the country as a whole is acceptable. It must be noted however, that routine freezing of large volumes of PCs, as is the case in some Centers, is not to be accepted.

The example of the Center in Białystok is a good illustration that freezing is not to be abandoned completely. Although in 2020, the Center did not perform freezing procedures, it did issue $3.9 \%$ of thawed PCs for clinical use. Current indications for the use of thawed PCs are limited. The components should be used only in exceptional cases, mostly for patients with anti-HLA or anti-HPA antibodies. Therefore it is not recommended to freeze more than $10 \%$ of all PCs prepared. This does not refer to freezing of apheresis PCs collected from patients with anti-HLA or anti-HPA antibodies.

It should be emphasized that freezing and thawing negatively affect the quality parameters of 
platelets and their therapeutic efficacy. However, in specific circumstances - as in the pandemic year 2020 - thawed PCs may prove to be the only option for patients who require frequent transfusions.

It is the Centers that are obliged to safeguard the supply of blood/blood components; however, to fulfill this task they need to cooperate with hospitals and such cooperation requires implementation of appropriate management of blood and blood components in every hospital, taking into account the individual needs of patients. The currently available data demonstrate that the ongoing cooperation between Centers and hospitals calls for significant changes which need to be preceded by extensive training activity aimed at increasing the awareness of the principles related to the above-mentioned issues. Training activity should be the responsibility of Centers on the one hand and the hospitals on the other. It is of utmost importance to establish constant cooperation between hospital transfusion committees and the Centers.

Depletion of blood and blood component supplies is associated with wastage which — though sometimes inevitable - occurs for a number of reasons. In order to limit the extent of waste of blood and blood components some countries have implemented special procedures [38].

The most common causes of wastage in 2020 (as in previous years) belong to the category of "other reasons", in particular:

— inadequate visual control;

— incorrect/low volume;

- seropositive test results;

- incorrect procedures, medical deferral, mechanical damage, donor self-deferral etc.

Expiry date or positive results of viral tests were less frequently the cause of waste. Subjected to waste were also unused blood components from autologous donations.

Data related to quarantine and pathogen inactivated FFP and cryoprecipitate reveal that quarantine FFP is still most commonly used in clinical practice. Although all Centers are equiped with PRT systems (some with two different systems) most of them did not make adequate use of the illuminators installed on their premises. With the exception of several Centers (in which the percentage of pathogen inactivated blood components exceeds 10\%) in most Centers only" "trace amounts" of plasma and $\mathrm{PC}$ are subjected to pathogen inactivation. In $2020 \mathrm{r}$. the Mirasol PRT system was implemented for plasma inactivation in the Centers in Radom, Slupsk and Wałbrzych, and they were mainly applied for inactivation of convalescent plasma (just like in all other Centers). Neither the Center in Slupsk nor in Radom applied pathogen inactivation to „conventional” FFP, while the Center in Wałbrzych subjected to pathogen inactivation only $2.66 \%$ of FFP. On the other hand, the Center in Radom subjected to pathogen inactivation more than $40 \%$ of apheresis PCs. The Center which applies pathogen inactivation on a large scale is again Warsaw $(6.83 \% \mathrm{FFP}$, $100 \%$ pooled PCs, $98.13 \%$ apheresis PCs). In 2020, the Center in Lublin gave up applying pathogen inactivation to PCs. In 2020, the Centers in Kalisz, Olsztyn, Opole and Zielona Góra implemented the Theraflex PRT system mainly for convalescent plasma. In 2020, the Centers in Białystok, Radom and Szczecin implemented the Intercept PRT system (in Białystok - for purposes of validation).

As in the previous years, most Centers do not make adequate use of pathogen inactivation systems implemented on their premises. The most likely reason is that physicians rarely make orders for pathogen inactivated FFP, cryoprecipitate and $\mathrm{PCs}$. One reason for limited use of pathogen inactivated plasma is the easy access to quarantine FFP. On the other hand, physicians who order components for clinical use are not always fully aware that pathogen inactivated plasma is much safer than quarantine plasma; it offers protection against the consequences of the "diagnostic window” (just like quarantine plasma) but also prevents the transmission of a wide spectrum of pathogens other than HIV, HBV, HCV and syphilis.

It is also likely that physicians do not always have sufficient knowledge and awareness regarding TA-GVHD prophylaxis which may be due to inadequate information on transfusion-related adverse reactions that appear in guidelines/regulations dedicated to some medical disciplines.

There is no justification however, for the sometimes observed procedure of physician's order for PCs subjected to pathogen inactivation(with one of the above mentioned systems) and also irradiated. Such procedure is incorrect, because the use of both gamma irradiation and inactivation may induce platelet activation which contributes to faster removal of platelets from the recipient's circulatory system [39].

\section{Conclusions}

The study is a brief presentation of selected issues related to the activities of the Polish Blood Transfusion Centers (Centers) in 2020, as well as some recently recorded trends of changes observed 
over a longer period of time. As compared to the previous years, almost all values related to the activity of the Polish blood transfusion service (including the number of donors, donations, blood components prepared and issued for clinical use) have been observed to decrease which is most probably due to the ongoing COVID-19 pandemic.

The observations may serve as starting point for the analysis of issues related to the activities of healthcare units in the Polish blood transfusion service, for comparison of experience and development of optimal solutions for the future. Similar data reviews related to blood and blood components are systematically performed in other countries.

\section{Current problems of blood transfusion medicine}

In 2020, blood transfusion service had to face problems that were largely related to the COVID-19 pandemic.

As result of rapid escalation of SARS-CoV-2 infections, on March $11^{\text {th }} 2020$ the World Health Organization (WHO) declared the COVID-19 pandemic. This brought about several important challenges for blood transfusion service:

- implementation of additional precautionary measures in blood collecting units;

- introduction of additional criteria for blood donor deferral;

- facing new tasks related to predicted blood component shortages, planning emergency actions and priority setting of supplies for clinical use [40].

From the point of view of blood transfusion medicine the following pandemic-related issues were most relevant:

- impact of the COVID-19 pandemic on the supply of blood components for clinical use and the need to secure adequate protection for patients in this respect;

- likely impact of COVID-19 infection on blood and the hematopoietic system which may lead to increased demand for blood components used as substitutive therapy;

- concerns about the possibility of disease transmission through transfusion of blood and components;

- tasks related to the collection and clinical use of convalescent plasma for COVID-19 patients as passive immunotherapy.

One important consequence of the ongoing COVID-19 pandemic is blood and blood component shortage observed in so many countries. The cir- cumstances have led to the focus of attention on rational blood therapy, reduction in the number of allogenic blood transfusions as well as on the optimal use of the patient's own blood [41].

A number of international organizations, including the European Center for Disease Prevention and Control (ECDC), have emphasized the importance of implementation and applying the principles of Patient Blood Management (PBM) in this situation of crisis [42].

The consequences of the COVID-19 pandemic are serious both for the blood transfusion service and transfusion medicine. Patients should be ensured timely access to safe blood and blood components and the main task of Centers is to safeguard the health of patients in this respect.

\section{Acknowledgements}

The authors express their thanks to the National Blood Center and the Blood Transfusion Centers for access to the relevant information and for their support in the analysis of the forwarded data.

\section{References}

1. Ustawa $z$ dnia 22 sierpnia 1997 r. o publicznej służbie krwi (Dz. U. Nr 106, poz. 681 z późn. zmian.).

2. Osselaer JC, Cazenave JP, Lambermont M, et al. An active haemovigilance programme characterizing the safety profile of 7437 platelet transfusions prepared with amotosalen photochemical treatment. Vox Sang. 2008; 94(4): 315-323, doi: 10.1111/j.1423-0410.2007.01035.x, indexed in Pubmed: 18248574.

3. Schlenke P. Pathogen inactivation technologies for cellular blood components: an update. Transfus Med Hemother. 2014; 41(4): 309-325, doi: 10.1159/000365646, indexed in Pubmed: 25254027.

4. Grass JA, Wafa T, Reames A, et al. Prevention of transfusion-associated graft-versus-host disease by photochemical treatment. Blood. 1999; 93(9): 3140-3147, indexed in Pubmed: 10216113.

5. Farmer S, Trentino K, Hofmann A, et al. A Programmatic Approach to Patient Blood Management - Reducing Transfusions and Improving Patient Outcomes. Open Anesthesiol J. 2015; 9(1): 6-16, doi: 10.2174/1874321801509010006.

6. van Hoeven, Koopman MMW, Koffijberg H, et al. Historical time trends in red blood cell usage in the Netherland. Intl J Clin Transf Med. 2016; 4: 67-77.

7. Ellingson KD, Sapiano MRP, Haass KA, et al. Continued decline in blood collection and transfusion in the United States-2015. Transfusion. 2017; 57 Suppl 2: 1588-1598, doi: 10.1111/trf.14165, indexed in Pubmed: 28591469.

8. WHO Expert Group. Expert Consensus Statement on achieving self-sufficiency in safe blood and blood products, based on voluntary non-remunerated blood donation (VNRBD). Vox Sang. 2012; 103(4): 337-342, doi: 10.1111/j.1423-0410.2012.01630.x, indexed in Pubmed: 22690746.

9. World Health Organization. Towards Self-Sufficiency in Safe Blood and Blood Products based on Voluntary Non-Remunerated Donation. Global Status.; 2013. 
10. Główny Urząd Statystyczny, Komitet Redakcyjny. Rocznik demograficzny; 2012.

11. Główny Urząd Statystyczny Rocznik Demograficzny 2021 https://stat gov pl/obszary-tematyczne/roczniki-statystyczne/ roczniki-statystyczne/rocznik-demograficzny-2021,3; 15: html.

12. Pogłód R, Rosiek A, Grabarczyk P, et al. Charakterystyka podstawowych wskaźników dotyczących krwiodawstwa i krwiolecznictwa w Europie - aktualne wyzwania i działania. J Transf Med. 2015; 8(2): 60-77.

13. Mikołowska A, Antoniewicz-Papis J. Retrospektywna analiza wybranych aspektów działalności publicznej służby krwi jako punkt wyjścia do oceny stanu polskiego krwiodawstwa. Część 1: Charakterystyka struktury demograficznej zbiorowości dawców. J Transf Med. 2020; 13(1): 29-66.

14. Napp S, Petrić D, Busquets N. West Nile virus and other mosquito-borne viruses present in Eastern Europe. Pathog Glob Health. 2018; 112(5): 233-248, doi: 10.1080/20477724.2018.1483567, indexed in Pubmed: 29979950.

15. Grabarczyk P, Niczyporuk J, Czupryna P, et al. Rekomendacje dotyczące ograniczania przenoszenia wirusa Zachodniego Nilu (WNV) przez transfuzje krwi oraz jej składników na terenie Polski. J Transf Med. 2020; 13(4): 228-238.

16. Siński E. Pasożytnicze pierwotniaki krwi potencjalnym zagrożeniem bezpieczeństwa krwiodawstwa w świetle doniesień prezentowanych na konferencji „Aktualne problemy dotyczące czynników zakaźnych przenoszonych przez krew" (10 marca 2017 r., Warszawa). J Transf Med. 2017; 10(2): 67-72.

17. Stramer SL, Hollinger FB, Katz LM, et al. Emerging infectious disease agents and their potential threat to transfusion safety. Transfusion. 2009; 49 Suppl 2: 1S-29S, doi: 10.1111/j.1537-2995.2009.02279.x, indexed in Pubmed: 19686562.

18. Jimenez A, Shaz BH, Bloch EM. Zika Virus and the Blood Supply: What Do We Know? Transfus Med Rev. 2017; 31(1): 1-10, doi: 10.1016/j.tmrv.2016.08.001, indexed in Pubmed: 27569055.

19. Rosiek A, Tomaszewska A, Lachert E, et al. Obniżone stężenie hemoglobiny najczęstszą przyczyną dyskwalifikacji krwiodawców na terenie polski. Acta Haematol Polonica. 2015; 46: 24, doi: 10.1016/j.achaem.2015.07.044.

20. Goldman M, Magnussen K, Gorlin J, et al. International Forum regarding practices related to donor haemoglobin and iron. Vox Sang. 2016; 111(4): 449-455, doi: 10.1111/vox.12431, indexed in Pubmed: 27564140.

21. Vuk T, Magnussen K, De Kort W, et al. International forum: an investigation of iron status in blood donors. Blood Transfus. 2017; 15(1): 20-41, doi: 10.2450/2016.0101-16, indexed in Pubmed: 27643753.

22. Vassallo R, Goldman M, Germain M, et al. BEST Collaborative. Preoperative Autologous Blood Donation: Waning Indications in an Era of Improved Blood Safety. Transfus Med Rev. 2015; 29(4): 268-275, doi: 10.1016/j.tmrv.2015.04.001, indexed in Pubmed: 26006319 .

23. European Directorate for the Quality of Medicines and HealthCare (EDQM). Guide to the preparation, use and quality assurance of blood components: recommendation No. R (95) 15, wyd.; 20: 2020.

24. Główny Urząd Statystyczny. Ludność. Stan i struktura ludności oraz ruch naturalny $\mathrm{w}$ przekroju terytorialnym (stan $\mathrm{w}$ dniu 31.12.2019). https://stat.gov.pl/obszary-tematyczne/ludnosc/ludnosc/ludnosc-stan-i-struktura-ludnosci-oraz-ruch-naturalny-w-przekroju-terytorialnym-stan-w-dniu-31-12-2019, 6, 27. html\# [online].

25. Główny Urząd Statystyczny, Komitet Redakcyjny. Rocznik demograficzny; 2017.
26. Główny Urząd Statystyczny, Komitet Redakcyjny. Rocznik demograficzny; 2015.

27. Główny Urząd Statystyczny, Komitet Redakcyjny. Rocznik demograficzny; 2016.

28. Komitet Redakcyjny Głównego Urzędu Statystycznego. Rocznik demograficzny; 2019.

29. Rosiek A, Tomaszewska A, Lachert E, et al. Działalność jednostek organizacyjnych służby krwi w Polsce w 2015 roku. J Transf Med. 2016; 9(4): 1-18.

30. Rosiek A, Tomaszewska A, Lachert E, et al. Działalność jednostek organizacyjnych slużby krwi w Polsce w 2016 roku. J Transf Med. 2017; 10(4): 113-129.

31. Rosiek A, Tomaszewska A, Lachert E, et al. Działalność jednostek organizacyjnych służby krwi w Polsce w 2017 roku. J Transf Med. 2018; 11(4): 113-130.

32. Rosiek A, Tomaszewska A, Lachert E, et al. Działalność jednostek organizacyjnych służby krwi w Polsce w 2018 roku. J Transf Med . 2019; 12(4): 127-143.

33. Rosiek A, Tomaszewska A, Lachert E, et al. Działalność jednostek organizacyjnych służby krwi w Polsce w 2019 roku. J Transf Med. 2020; 13(4): 195-211.

34. NICE. Blood transfusion. NICE guideline. Published: 18 November 2015. nice.org.uk/guidance/ng24 [Online]. [Online].

35. Klein AA, Arnold P, Bingham RM, et al. AAGBI guidelines: the use of blood components and their alternatives 2016. Anaesthesia. 2016; 71(7): 829-842, doi: 10.1111/anae.13489, indexed in Pubmed: 27062274.

36. Estcourt LJ. Why has demand for platelet components increased? A review. Transfus Med. 2014; 24(5): 260-268, doi: 10.1111/ tme.12155, indexed in Pubmed: 25327286.

37. Simancas-Racines D, Osorio D, Martí-Carvajal AJ, et al. Leukoreduction for the prevention of adverse reactions from allogeneic blood transfusion. Cochrane Database Syst Rev. 2015(12): CD009745, doi: 10.1002/14651858.CD009745.pub2, indexed in Pubmed: 26633306.

38. Heitmiller ES, Hill RB, Marshall CE, et al. Blood wastage reduction using Lean Sigma methodology. Transfusion. 2010; 50(9): 1887-1896, doi: 10.1111/j.1537-2995.2010.02679.x, indexed in Pubmed: 20456700.

39. Apelseth $\mathrm{\emptyset}$, Bruserud $\emptyset$, Wentzel-Larsen T, et al. In vitro evaluation of metabolic changes and residual platelet responsiveness in photochemical treated and gamma-irradiated single-donor platelet concentrates during long-term storage. Transfusion. 2007; 47(4): 653-665, doi: 10.1111/j.1537-2995.2007.01167.x, indexed in Pubmed: 17381624.

40. Stanworth SJ, New HV, Apelseth TO, et al. Effects of the COVID-19 pandemic on supply and use of blood for transfusion. Lancet Haematol. 2020; 7(10): e756-e764, doi: 10.1016/S23523026(20)30186-1, indexed in Pubmed: 32628911.

41. Baron DM, Franchini M, Goobie SM, et al. Patient blood management during the COVID-19 pandemic: a narrative review. Anaesthesia. 2020; 75(8): 1105-1113, doi: 10.1111/anae.15095, indexed in Pubmed: 32339260.

42. European Centre for Disease Prevention and Control. Coronavirus disease - 2019 (COVID-19) and supply of substances of human origin in EU/EEA - first update. April 2020 . https:// www.ecdc.europa.eu/sites/default/files/documents/COVID\%20 19-supply-substances-human-origin-first-update.pdf.

43. Rabel PO, Planitzer CB, Farcet MR, et al. Increasing West Nile virus antibody titres in central European plasma donors from 2006 to 2010. Euro Surveill. 2011; 16(10), doi: 10.2807/ ese.16.10.19812-en, indexed in Pubmed: 21435324. 